\title{
Plumage polymorphism and variation in the melanocortin-1 receptor gene in the Fuscous Flycatcher, Cnemotriccus fuscatus (Wied, 1831)
}

\author{
Sandriéllem Natália Vieira ${ }^{1}$, Juliana Araripe ${ }^{1}$, Alexandre Aleixo² \& Péricles Sena do Rêgo ${ }^{1,3}$ \\ Laboratório de Genética e Conservação, Instituto de Estudos Costeiros, Universidade Federal do Pará, 68600-000, Bragança, PA, Brazil. \\ Coordenação de Zoologia, Museu Paraense Emílio Goeldi, Belém, PA, Brazil. \\ Corresponding author: periclessena@yahoo.com.br
}

Received on 26 October 2017. Accepted on 03 December 2018.

\begin{abstract}
We investigated the possible mechanisms behind the variation plumage color of the Fuscous Flycatcher, Cnemotriccus fuscatus, by sequencing the melanocortin-1 receptor $(M C 1 R)$ gene, which has been associated with the variation in plumage coloration in birds. C. fuscatus is widely distributed in South America and includes seven subspecies, which differ in their plumage coloration. Here we tested the hypothesis that the variation in the $M C 1 R$ gene explains the plumage polymorphism found in $C$. fuscatus. We sequenced the $M C 1 R$ gene in six subspecies, representing two groups: group 1 (yellow morph), with three subspecies, $C$. $f$. duidae, C. f. fumosus, and C. f. fuscatus, and group 2 (white morph), with the remaining subspecies, C. f. bimaculatus, C. f. beniensis, and C. $f$. fuscatior. The only variation we found among the $C$. fuscatus sequences were six non-synonymous substitutions from 22 variable sites, none of which were associated systematically with either plumage morph. The result of the neutrality test indicated that the polymorphism of the MC1R gene is not suggestive of significant selection pressure. We conclude that variation in plumage coloration in $C$. fuscatus does not appear to be determined by the $M C 1 R$ gene, and that it may be related to other loci or under the influence of environmental factors.
\end{abstract}

KEY-WORDS: birds, MC1R gene, mutation, pigmentation, Tyrannidae.

\section{INTRODUCTION}

The variation in plumage coloration has been studied from ecological, evolutionary and genetic perspectives (Hoekstra \& Price 2004, Mundy 2005, Uy et al. 2016). Such diversity has been related to visual communication, and may have evolved in response to the evolution of the avian visual system (Osorio \& Vorobyev 2008), although there is also some evidence that changes in plumage coloration may be a response to varying pressures in different types of habitat (Gomez \& Théry 2004, McNaught \& Owens 2002). Many questions remain unresolved, however, on the evolution of plumage coloration and its relation to speciation in birds (Stoddard \& Prum 2011, Seddon et al. 2013), such as the mechanisms that mediate the change in coloration between juveniles and adults (Galván \& Jorge 2015), and the factors determining changes in coloration despite the considerable energetic costs of this process (Legagneux et al. 2012, Mercadante \& Hill 2014).

Previous studies (e.g., Robbins et al. 1993, Vidal et al. 2010, Johnson et al. 2012) have suggested that the melanocortin-1 receptor $(M C 1 R)$ gene may be involved in the differentiation of the plumage in avian species, due to the association between mutations in this gene and the phenotypic variation found in a number of different groups of wild birds (Johnson et al. 2012, Ran et al. 2016). For example, single non-synonymous mutations in the MC1R gene were associated with plumage polymorphisms in the bananaquit (Coereba flaveola) and the chestnut-bellied monarch, Monarcha castaneiventris (Theron et al. 2001, Uy et al. 2009). Studies in birds have also shown that the $M C 1 R$ gene controls the amount of both eumelanin (brown/black) and pheomelanin (red/ yellow) produced (Takeuchi et al. 1996, Wen et al. 2015). In particular, García-Borrón et al. (2005) showed that the yellow (pheomelanin) phenotype is produced by recessive $M C 1 R$ extension (e) alleles.

In this context, we investigated the variation in coloration found among the subspecies of the Fuscous Flycatcher, Cnemotriccus fuscatus, a monotypic genus widely distributed in South America (Fig. 1). There are seven $C$. fuscatus subspecies, which are differentiated not only on the basis of their morphological characters, but also their vocalizations and ecology (Fitzpatrick et al. 2004). These subspecies can be divided into two groups, 
based primarily on the coloration of the belly, which is either white or yellow. These flycatchers can be found in a variety of habitats, including fluvial islands, rainforest, dry forests, riparian habitats, and lowland and secondary forests (Rasmussen \& Collar 2002). It is thus important to understand which factors may influence the variation in the coloration of plumage found among the different subspecies of the Fuscous Flycatcher (Farnsworth \& Lebbin 2017). In particular, if a relationship can be found between genotype and phenotype, it might represent evidence of the role of natural selection in the fixation of subspecific coloration patterns (Hewitt 1988, Chunco et al. 2007).

Here we investigated the possible mechanisms that determine differentiation in plumage amongst the subspecies of $C$. fuscatus. Specifically, we tested whether non-synonymous mutations in the sequence of the melanocortin-1 receptor $(M C 1 R)$ gene were associated systematically with variation in plumage coloration amongst the six subspecies, and whether these mutations are suffering selection pressures.

\section{METHODS}

We sequenced 27 samples of Cnemotriccus fuscatus muscle tissue (Table 1), representing six of the seven described subspecies. The samples were provided by the Goeldi Museum (MPEG: Museu Paraense Emilio Goeldi) in
Belém, and the National Museum (MNRJ) in Rio de Janeiro. We followed the classification of Fitzpatrick et al. (2004) to allocate the subspecies to two groups (yellow and white morphs). Group 1 (yellow morph) was composed of Cnemotriccus fuscatus duidae ( $n=5$ specimens), Cnemotriccus fuscatus fumosus ( $n=7$ ), and Cnemotriccus fuscatus fuscatus $(n=5)$, which are ventrally yellow to light yellow. Group 2 (white morph) contained the other three subspecies, Cnemotriccus fuscatus bimaculatus $(n=5)$, Cnemotriccus fuscatus beniensis $(n=3)$, and Cnemotriccus fuscatus fuscatior $(n=2)$, which are ventrally white or light gray. Both male and female specimens were included, as C. fuscatus is not dichromatic (Fitzpatrick et al. 2004).

Total DNA was isolated from the muscle tissue using the Wizard ${ }^{\odot}$ Genomic DNA purification kit (Promega), following the manufacturer's instructions. To obtain a partial sequence of the $M C 1 R$ gene, we amplified the samples by PCR using the primers described by Cheviron et al. (2006): lcorMSHR9 (5' - CTG GCT CCG GAA GGC RTA GAT - 3') and lcorMSHR72 (5' - AYG CCA GYG AGG GCA ACC A - 3'). The PCR conditions were the same as those used by Cheviron et al. (2006), and the PCR products were sequenced by Sanger's didesoxiterminal method (Sanger et al. 1977), using an ABI 3500 automatic sequencer.

The DNA sequences were aligned and their nucleotides were compared to those from the bananaquit, Coereba flaveola (GenBank access numbers AF362598 and AF362601) and Gallus gallus (AB201631) using Bioedit

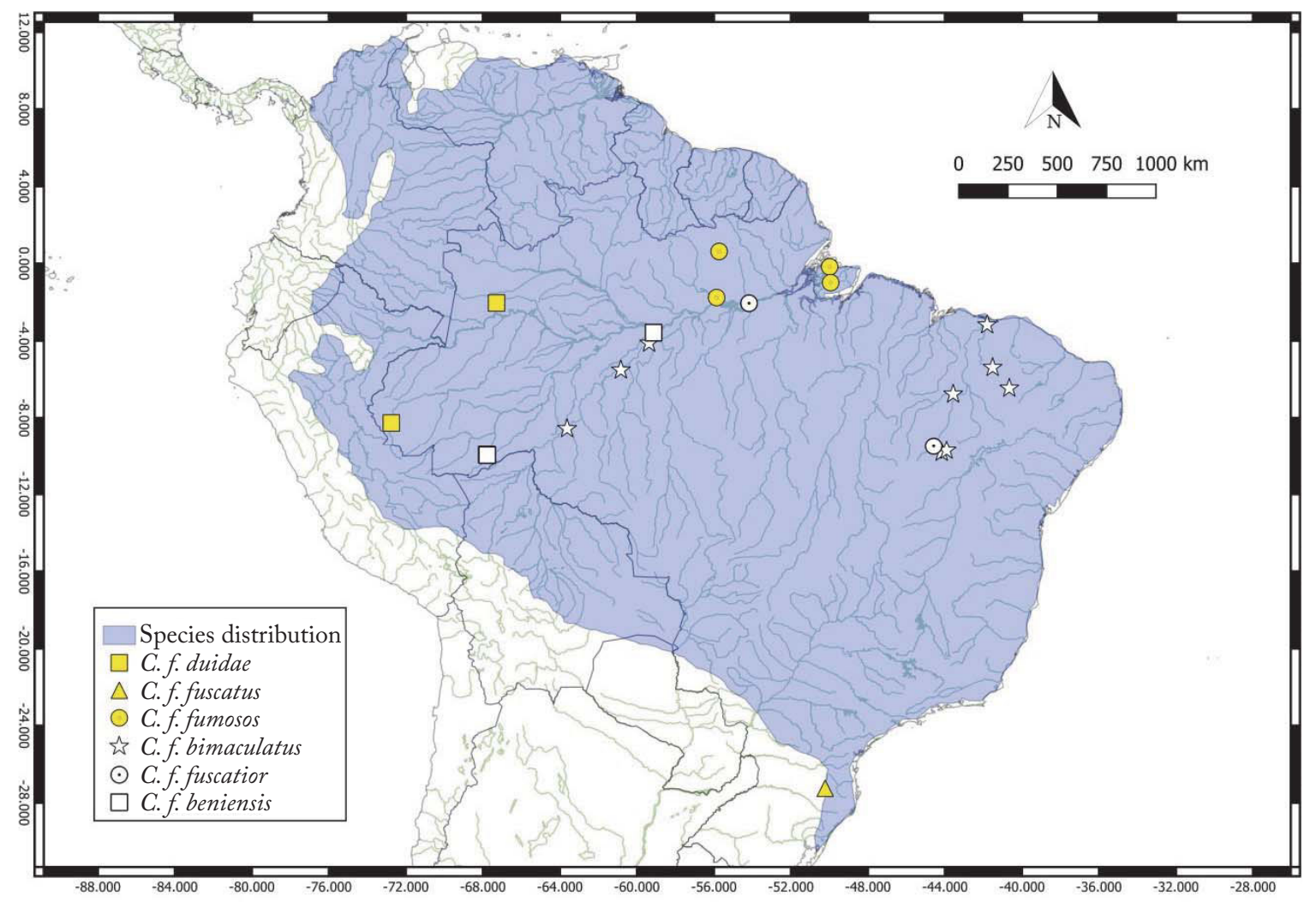

Figure 1. Map showing the distribution of samples of Cnemotriccus fuscatus sequenced in this study. Yellow points represent specimens with yellow bellies and white points denote specimens with white bellies. 
Table 1. Location, coordinates, subspecies, voucher number, identification code, and source of tissue used in this study.

\begin{tabular}{|c|c|c|c|c|}
\hline $\begin{array}{l}\text { Locations } \\
\text { (Coordinates) }\end{array}$ & Subspecies & Voucher number & $\begin{array}{l}\text { Identification of } \\
\text { the tissue }\end{array}$ & Institutions \\
\hline $\begin{array}{l}\text { Óbidos - PA } \\
\left(00^{\circ} 37^{\prime} 50^{\prime \prime N}\right. \\
\left.55^{\circ} 43^{\prime} 40^{\prime \prime}\right)\end{array}$ & C.f. fumosus & CN1410, CN1378, & $\begin{array}{l}\text { Cfu1410, } \\
\text { Cfu1378 }\end{array}$ & MPEG $^{*}$ \\
\hline $\begin{array}{l}\text { Chaves - PA } \\
00^{\circ} 12^{\prime} 29.2^{\prime \prime} \mathrm{S} \\
49^{\circ} 58^{\prime} 39.2^{\prime \prime} \mathrm{W}\end{array}$ & C. f. fumosus & MARJ117, MARJ118 & Cfu118, Cfu117 & MPEG \\
\hline $\begin{array}{l}\text { Marajó - PA } \\
\left(00^{\circ} 59^{\prime} 21^{\prime \prime S}\right. \\
\left.49^{\circ} 56^{\prime} 24^{\prime \prime W}\right)\end{array}$ & C. f. fumosus & MAYA008 & Cfu008 & MPEG \\
\hline $\begin{array}{l}\text { Oriximiná - PA } \\
\left(1^{\circ} 45^{\prime} 36.89^{\prime \prime} \mathrm{S}\right. \\
\left.55^{\circ} 51^{\prime} 30.28^{\prime \prime} \mathrm{W}\right)\end{array}$ & C.f. fumosus & ORX336, ORX359 & Cfu336, Cfu359 & MPEG \\
\hline $\begin{array}{l}\text { Porto Walter - AC } \\
\left(08^{\circ} 20^{\prime} 35.7^{\prime \prime} \text {; }\right. \\
\left.72^{\circ} 36^{\prime} 19.7^{\prime \prime W}\right)\end{array}$ & C.f. duidae & UFAC1021 & Cfu1021 & MPEG \\
\hline $\begin{array}{l}\text { Japurá - AM } \\
\left(02^{\circ} 02^{\prime} 31.5^{\prime \prime} \mathrm{S}\right. \\
\left.67^{\circ} 17^{\prime} 16.6^{\prime \prime} \mathrm{W}\right)\end{array}$ & C.f. duidae & JAP225, JAP267, JAP270 & $\begin{array}{l}\text { Cfu225, Cfu267, } \\
\text { Cfu270 }\end{array}$ & MPEG \\
\hline $\begin{array}{l}\text { Porto Walter - AC } \\
\left(08^{\circ} 20^{\prime} 35.7^{\prime \prime} \mathrm{S}\right. \\
\left.72^{\circ} 36^{\prime} 19.7^{\prime \prime} \mathrm{W}\right)\end{array}$ & C.f. duidae & UFAC0976 & Cfu0976 & MPEG \\
\hline $\begin{array}{l}\text { Uruçuí - PI } \\
\left(07^{\circ} 14^{\prime} 2.00^{\prime \prime} \text {; }\right. \\
\left.44^{\circ} 33^{\prime} 1.55^{\prime \prime} \mathrm{W}\right)\end{array}$ & C.f. bimaculatus & URC171 & Cfu171 & MPEG \\
\hline $\begin{array}{l}\text { Curimatá - PI } \\
\left(09^{\circ} 41^{\prime} 284^{\prime \prime S} ;\right. \\
\left.44^{\circ} 14^{\prime} 200^{\prime \prime W}\right)\end{array}$ & C.f. bimaculatus & SRV005 & Cfu005 & MPEG \\
\hline $\begin{array}{l}\text { Redenção do Gurgueia - PA } \\
\left(9^{\circ} 38^{\prime} 022^{\prime \prime} \mathrm{S} ;\right. \\
\left.44^{\circ} 08^{\prime} 807^{\prime \prime} \mathrm{W}\right)\end{array}$ & C.f. bimaculatus & SRV042 & CfuS042 & MPEG \\
\hline $\begin{array}{l}\text { Borba, Puruzinho, Ilha - AM } \\
04^{\circ} 07^{\prime} 42^{\prime \prime} \mathrm{S} ; \\
59^{\circ} 21^{\prime} 55.4^{\prime \prime} \mathrm{W}\end{array}$ & C.f. bimaculatus & MAD 500 & Cfu500 & MPEG \\
\hline $\begin{array}{l}\text { Autazes, Uricurituba, Ilha - AM } \\
03^{\circ} 34^{\prime} 47^{\prime \prime} \mathrm{S} ; \\
59^{\circ} 07^{\prime} 50^{\prime \prime} \mathrm{W}\end{array}$ & C.f. bimaculatus & MAD608 & Cfu608 & MPEG \\
\hline $\begin{array}{l}\text { Santa Catarina - SC } \\
\left(27^{\circ} 14^{\prime} 32.42^{\prime \prime} S\right. \\
\left.50^{\circ} 13^{\prime} 7.88^{\prime \prime} \mathrm{W}\right)\end{array}$ & C. f. fuscatus & $\begin{array}{c}\text { TERNA210, } \\
\text { TERNA398,TERNA1068, } \\
\text { TERNA1349, Cachimbo470 }\end{array}$ & $\begin{array}{l}\text { Cfu210, Cfu398, } \\
\text { Cfu1068, } \\
\text { Cfu1349, Cfu470 }\end{array}$ & $\mathrm{MNRJ}^{\dagger}$ \\
\hline $\begin{array}{l}\text { Rio Branco - AC } \\
\left(09^{\circ} 57^{\prime} 32.3^{\prime \prime} \mathrm{S}\right. \\
\left.67^{\circ} 43^{\prime} 57.2^{\prime \prime} \mathrm{W}\right)\end{array}$ & C. f. beniensis & $\begin{array}{c}\text { UFAC1199, UFAC1297, } \\
\text { UFAC273 }\end{array}$ & $\begin{array}{c}\text { Cfu1199, } \\
\text { Cfu1297, Cfu273 }\end{array}$ & MPEG \\
\hline $\begin{array}{l}\text { Monte Alegre - PA } \\
\left(2^{\circ} 3^{\prime} 14.72^{\prime \prime} \mathrm{S} ;\right. \\
\left.54^{\circ} 10^{\prime} 24.49^{\prime \prime} \mathrm{W}\right)\end{array}$ & C. f. fuscatior & PEMA042, PEMA037 & Cfu042, Cfu037 & MPEG \\
\hline
\end{tabular}

* Museu Paraense Emilio Goeldi.

$\dagger$ Museu Nacional do Rio de Janeiro. 
v. 7.2.5, to confirm the position of amplified fragment. We then assessed if aminoacid sequence presented stop codons and indels, which could indicate pseudogenes. The potential association of variable sites with the plumage morphotype of each species was confirmed by visual inspection. We calculated Tajima's D (Tajima 1989) in DnaSP (version 3.51, Rozas et al. 2003) to verify whether the $M C 1 R$ gene was under selection pressure in the two groups.

\section{RESULTS}

A total of 744 base pairs were sequenced for each of the 27 C. fuscatus samples, representing nucleotides 129873 of the MC1R gene of Gallus gallus, which includes all the sites known to be associated with plumage polymorphisms in birds (Theron et al. 2001). Only 21 samples were considered ( $\mathrm{pp}>0.6$ ) after the resolution of the gametic phases (Harrigan et al. 2008, Table 2). In the BLAST (NCBI: National Center for Biotechnology Information) analysis, the sequences were $95 \%$ similar to that of Gallus gallus (Kerje et al. 2003) and $97 \%$ similar to that of Coereba flaveola (Theron et al. 2001).

We identified 22 variable sites in the 21 C. fuscatus samples (Table 2), including all six subspecies. These variable sites of the $M C 1 R$ locus determined six nonsynonymous mutations for the codification of amino acids, A8G, S9R, S10N, S89N, V226I, and L240I (Table 3). None of these sites were associated with the coloration patterns of either the two groups or any of the subspecies. Tajima's D was not significant $(-1.603$, $P>0.05$ ), indicating that the variation found in the study locus in C. fuscatus is neutral, with a signal of recent demographic expansion, against the constant demographic model. All the sequences generated in the present study were deposited in GenBank (www. ncbi.nlm.nih.gov) under access numbers MK102986 through MK103006 (Table 3).

\section{DISCUSSION}

Our study of Cnemotriccus fuscatus indicates that there is no clear association between the plumage polymorphism found in this species and mutations of the MC1R gene. As in previous studies of bird species such as Phylloscopus toutinegras (MacDougall-Shackleton et al. 2003), Lepidothrix coronata (Cheviron et al. 2006), Dendrocolaptes platyrostris (Corso et al. 2013), Philomachus pugnax

Table 2. MC1R variable sites found in the sequences of Cnemotriccus fuscatus.

\begin{tabular}{|c|c|c|c|c|c|c|c|c|c|c|c|c|c|c|c|c|c|c|c|c|c|c|c|c|}
\hline \multirow{4}{*}{ Voucher - Subspecies } & \multicolumn{23}{|c|}{ Nucleotidic sites } & \multirow{4}{*}{ Belly Plumage } \\
\hline & \multirow{3}{*}{$\begin{array}{l}1 \\
5\end{array}$} & \multirow{3}{*}{$\begin{array}{l}2 \\
3\end{array}$} & \multirow{3}{*}{$\begin{array}{l}2 \\
5\end{array}$} & \multirow{3}{*}{$\begin{array}{l}2 \\
9\end{array}$} & & \multirow{3}{*}{$\begin{array}{l}1 \\
3 \\
8\end{array}$} & \multirow{3}{*}{$\begin{array}{l}1 \\
7 \\
2\end{array}$} & \multirow{3}{*}{$\begin{array}{l}1 \\
7 \\
2\end{array}$} & \multirow{3}{*}{$\begin{array}{l}2 \\
1 \\
3\end{array}$} & \multirow{3}{*}{$\begin{array}{l}2 \\
4 \\
3\end{array}$} & \multirow{3}{*}{$\begin{array}{l}2 \\
6 \\
6\end{array}$} & \multirow{3}{*}{$\begin{array}{l}2 \\
7 \\
6\end{array}$} & \multirow{3}{*}{$\begin{array}{l}3 \\
1 \\
8\end{array}$} & \multirow{2}{*}{$\begin{array}{l}3 \\
2\end{array}$} & \multirow{2}{*}{$\begin{array}{l}4 \\
6\end{array}$} & \multirow{2}{*}{$\begin{array}{l}4 \\
9\end{array}$} & \multirow{2}{*}{$\begin{array}{l}5 \\
0\end{array}$} & \multirow{2}{*}{$\begin{array}{l}6 \\
3\end{array}$} & \multirow{2}{*}{$\begin{array}{l}6 \\
4\end{array}$} & \multirow{2}{*}{$\begin{array}{l}6 \\
7\end{array}$} & \multirow{2}{*}{$\begin{array}{l}6 \\
8\end{array}$} & 7 & 7 & \\
\hline & & & & & & & & & & & & & & & & & & & & & & 1 & 2 & \\
\hline & & & & & & & & & & & & & & 7 & 5 & 8 & 4 & 3 & 8 & 6 & 7 & 8 & 3 & \\
\hline Cfu008 - C. f. fumosus & G & $\mathrm{C}$ & A & G & A & $\mathrm{C}$ & $\mathrm{C}$ & $\mathrm{C}$ & G & $\mathrm{C}$ & G & $\mathrm{C}$ & $\mathrm{C}$ & $\mathrm{T}$ & $\mathrm{C}$ & $\mathrm{C}$ & $\mathrm{C} / \mathrm{G}$ & $\mathrm{T}$ & $\mathrm{C}$ & G & $\mathrm{C}$ & $\mathrm{C} / \mathrm{A}$ & $\mathrm{C}$ & Yellow \\
\hline Cfu117- C.f. fumosus & . & . & . & . & . & . & . & . & . & & . & . & . & . & . & . & . & . & . & . & . & . & . & Yellow \\
\hline Cfu118 - C.f. fumosus & . & . & . & . & . & . & . & . & . & & . & . & . & . & . & . & . & . & . & . & ${ }^{\circ}$ & . & . & Yellow \\
\hline Cfu1410 - C.f. fumosus & . & . & . & . & . & . & . & . & . & & A & $\mathrm{T}$ & . & . & . & . & . & . & $\mathrm{T}$ & . & . & . & . & Yellow \\
\hline Cfu359 - C.f. fumosus & . & . & . & . & $\mathrm{A} / \mathrm{G}$ & . & . & . & . & & . & . & . & . & $\mathrm{T}$ & . & . & . & $\mathrm{T}$ & G/A & $\mathrm{T}$ & . & $\mathrm{T}$ & Yellow \\
\hline Cfu225 - C. f. duidae & . & . & . & . & . & . & . & . & . & & . & . & . & . & $\mathrm{T}$ & . & . & . & $\mathrm{T}$ & . & . & . & $\mathrm{T}$ & Yellow \\
\hline Cfu267- C.f. duidae & . & . & . & . & . & . & . & . & . & & A & $\mathrm{T}$ & . & . & . & . & . & . & $\mathrm{T}$ & . & $\cdot$ & . & $\mathrm{C} / \mathrm{T}$ & Yellow \\
\hline Cfu0976 - C.f. duidae & . & . & . & . & G/A & r. & . & . & . & & G/A & $\mathrm{C} / \mathrm{T}$ & . & . & . & . & . & . & $\mathrm{T}$ & . & 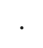 & . & . & Yellow \\
\hline Cfu1021 - C.f. duidae & . & . & . & . & $\mathrm{A} / \mathrm{G}$ & . & . & . & . & & . & . & . & . & . & . & . & . & $\mathrm{C} / \mathrm{T}$ & . & $\cdot$ & . & . & Yellow \\
\hline Cfu270 - C.f. duidae & . & . & . & . & G & . & . & . & . & & . & . & . & . & . & . & . & . & $\mathrm{T}$ & . & . & . & . & Yellow \\
\hline Cfu210 - C.f. fuscatus & . & . & . & . & . & . & . & . & . & & . & . & . & . & . & . & . & . & . & . & . & . & . & Yellow \\
\hline Cfu398 - C.f. fuscatus & . & . & . & . & . & . & . & . & . & & . & . & . & . & . & . & . & . & . & . & $\cdot$ & . & $\mathrm{C} / \mathrm{T}$ & Yellow \\
\hline Cfu1068 - C.f. fuscatus & . & . & . & . & . & . & . & . & . & & . & . & . & . & . & . & . & . & . & . & . & . & . & Yellow \\
\hline Cfu273 - C. f. beniensis & . & G & C & G/A & . & . & . & . & 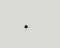 & & . & . & . & . & . & $\mathrm{C} / \mathrm{A}$ & . & . & . & . & & . & . & White \\
\hline Cfu1297 - C.f. beniensis & . & e & 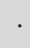 & . & . & . & . & $\mathrm{C} / \mathrm{T}$ & & & . & . & . & . & . & . & . & . & . & . & & . & . & White \\
\hline Cfu500 - C. f. bimaculatus & $\mathrm{A} / \mathrm{G}$ & & 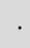 & . & . & . & . & $\mathrm{C} / \mathrm{T}$ & & & . & . & . & . & . & . & . & . & . & . & & . & . & White \\
\hline Cfu608 - C. f. bimaculatus & . & 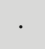 & ${ }^{\circ}$ & . & . & . & . & . & . & & . & . & . & . & . & . & . & . & . & . & & . & . & White \\
\hline Cfu005 - C. f. bimaculatus & . & . & 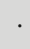 & . & G & . & . & $\cdot$ & $\mathrm{A} / \mathrm{G}$ & T/C & . & . & $\mathrm{C} / \mathrm{T}$ & $\mathrm{C} C$ & $\mathrm{C} / \mathrm{T}$ & . & . & . & . & . & & . & . & White \\
\hline Cfu042 - C. f. bimaculatus & . & 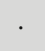 & 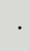 & . & . & 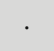 & . & . & & & . & . & . & . & . & . & . & . & . & . & & . & . & White \\
\hline Cfu171 - C. f. bimaculatus & . & $\cdot$ & . & . & . & . & . & . & . & & . & . & . & . & . & . & . & . & . & . & & . & . & White \\
\hline Cfu042 - C.f. fuscatior & . & & & . & 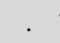 & $\mathrm{T} / \mathrm{C}$ & $\mathrm{T} / \mathrm{C}$ & 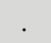 & & & . & . & & . & . & . & . & $\mathrm{C} / \mathrm{T}$ & & . & & . & $\mathrm{C} / \mathrm{T}$ & White \\
\hline
\end{tabular}


Table 3. Position of non-synonymous variations within the amino acid Cnemotriccus fuscatus. GenBank access numbers for the samples analyzed.

\begin{tabular}{|c|c|c|c|c|c|c|c|c|}
\hline \multirow{4}{*}{ Voucher - Subspecies } & \multicolumn{6}{|c|}{ Amino acid positions } & \multirow{4}{*}{ Belly Plumage } & \multirow{4}{*}{$\begin{array}{c}\text { Access number } \\
\text { GenBank }\end{array}$} \\
\hline & \multirow[b]{3}{*}{8} & \multirow[b]{3}{*}{9} & \multirow{3}{*}{$\begin{array}{l}1 \\
0\end{array}$} & \multirow{3}{*}{$\begin{array}{l}8 \\
9\end{array}$} & \multirow{3}{*}{$\begin{array}{l}2 \\
2 \\
6\end{array}$} & \multirow{3}{*}{$\begin{array}{l}2 \\
4 \\
0\end{array}$} & & \\
\hline & & & & & & & & \\
\hline & & & & & & & & \\
\hline Cfu008 - C.f. fumosus & $\mathrm{A}$ & $S$ & $S$ & $S$ & $\mathrm{~V}$ & $\mathrm{~L} / \mathrm{I}$ & Yellow & MK102986 \\
\hline Cfu117 - C. f. fumosus & - & - & - & - & - & - & Yellow & MK102987 \\
\hline Cfu118 - C.f. fumosus & . & . & . & . & . & . & Yellow & MK102988 \\
\hline Cfu1410 - C.f. fumosus & . & . & . & $\mathrm{N}$ & . & . & Yellow & MK102989 \\
\hline Cfu359 - C.f. fumosus & . & . & . & . & $\mathrm{V} / \mathrm{I}$ & . & Yellow & MK102990 \\
\hline Cfu225 - C. f. duidae & . & . & • & . & . & . & Yellow & MK102991 \\
\hline Cfu267 - C.f. duidae & . & . & . & $\mathrm{N}$ & . & . & Yellow & MK102992 \\
\hline Cfu0976 - C.f. duidae & . & . & . & $\mathrm{S} / \mathrm{N}$ & . & . & Yellow & MK102993 \\
\hline Cfu1021 - C.f. duidae & . & . & . & . & . & . & Yellow & MK102994 \\
\hline Cfu270 - C.f. duidae & . & . & . & . & . & . & Yellow & MK102995 \\
\hline Cfu210 - C.f. fuscatus & . & . & • & • & . & . & Yellow & MK102996 \\
\hline Cfu398 - C.f. fuscatus & - & . & • & • & . & . & Yellow & MK102997 \\
\hline Cfu1068 - C.f. fuscatus & . & . & . & . & . & . & Yellow & MK102998 \\
\hline Cfu273 - C.f. beniensis & G & $\mathrm{R}$ & $\mathrm{S} / \mathrm{N}$ & . & . & . & White & MK102999 \\
\hline Cfu1297 - C. f. beniensis & . & . & - & . & . & . & White & MK103000 \\
\hline Cfu500 - C.f. bimaculatus & . & . & . & . & . & . & White & MK103001 \\
\hline Cfu608 - C.f. bimaculatus & . & . & . & . & . & . & White & MK103002 \\
\hline Cfu005 - C.f. bimaculatus & . & . & . & . & . & . & White & MK103003 \\
\hline Cfus042 - C.f. bimaculatus & . & . & . & . & . & . & White & MK103004 \\
\hline Cfu171 - C. f. bimaculatus & - & . & . & • & . & . & White & MK103005 \\
\hline Cfu042 - C. f. fuscatior & . & . & . & . & . & . & White & MK103006 \\
\hline
\end{tabular}

(Farrell et al. 2014) and the genus Antilophia (Luna et al. 2018), our findings reinforce the conclusion that this gene does not always play a role in the variation in plumage coloration found among populations or species. In this case, other genes or mechanisms may determine this variation, as observed in a number of birds (McLean \& Stuart-Fox 2014).

A number of new genes associated with plumage coloration have been identified in recent years, although they have been analyzed in only a few species (Oribe et al. 2012, Bourgeois et al. 2016). Miwa et al. (2007), for example, found an association between mutations of the endothelin receptor B2 (EDNRB2) gene and the coloration of Cortunix japonica, with a non-synonymous substitution that alters an amino acid $(R 332 H)$ being associated with the "panda" pattern, in contrast with the standard "dotted white" pattern. Other genes that may be involved in pigmentation in birds include the tyrosinaserelated protein 1, TYRP1 (Xu et al. 2013, Bourgeois et al.
2016), SRY-Box containing 10, SOX10 (Gunnarsson et al. 2011), Agouti protein, ASIP (Oribe et al. 2012, Zhang et al. 2013), and Corin (Bourgeois et al. 2016) genes, and the proopiomelanocortin $(P O M C)$ gene cluster, which includes $M C 1 R$ (Kang \& Kim 2015).

In addition to genetics, the variation found in the coloration of $C$. fuscatus may be related to environmental factors, given the diversity of habitats occupied by the species (Fig. 1). Uy et al. (2009), for example, found that natural selection may favor distinct coloration in different habitats based on the existence of several population patterns, with habitats dominated by short-wavelength light (e.g., shaded woodland) favoring darker birds, and habitats rich in long-wavelength light (e.g., forest clearings with direct sunlight) favor lighter-colored species.

Furthermore, the studied part of the gene MC1R includes all the main sites that were showed in previous research with plumage polymorphism of birds (Mundy 2005, Cheviron et al. 2006). Overall, our results reinforce 
the conclusion that understanding the evolution of plumage coloration in C. fuscatus with varying patterns of eumelanin/pheomelanin pigmentation requires a more profound investigation of the genes in the melanocortin pathway and their potential variation, as well as other loci and environmental factors. Unlike many other bird species (see e.g., Cheviron et al. 2006, Corso et al. 2013, Farrell et al. 2014, Luna et al. 2018), the variation in the plumage coloration of $C$. fuscatus does not appear to be related to mutations of the $M C 1 R$ gene.

\section{ACKNOWLEDGEMENTS}

We thank the Goeldi Museum (MPEG) and National Museum (MNRJ) for providing samples. We are also grateful to the Federal University of Pará (UFPA) for infrastructure, the Institutional Program of Scientific Initiation Scholarships (PIBIC) for granting an undergraduate scholarship, the CAPES Science Without Borders (CSF) program for supporting overseas academic exchange and Stephen Ferrari for the revision of the manuscript. A.A. is supported by a $\mathrm{CNPq}$ research productivity fellowship (\# 306843/2016-1).

\section{REFERENCES}

Bourgeois Y.X.C., Bertrand J.A.M., Delahaie B., Cornuault J., Duval T., Milá B. \& Thébaud C. 2016. Candidate gene analysis suggests untapped genetic complexity in melanin-based pigmentation in birds. Journal of Heredity 107: 327-335.

Cheviron Z.A., Hackett S.J. \& Brumfield R.T. 2006. Sequence variation in the coding region of the melanocortin-1 receptor gene (MC1R) is not associated with plumage variation in the Bluecrowned Manakin (Lepidothrix coronata). Proceedings of the Royal Society of London B: Biological Sciences 273: 1613-1618.

Chunco A.J., McKinnon J.S. \& Servedio M.R. 2007. Microhabitat variation and sexual selection can maintain male color polymorphisms. Evolution 61: 2504-2515.

Corso J., Cabanne G.S., d'Horta F.M., Loreto É.L.S. \& Miyaki C.Y. 2013. Plumage variation in the Planalto Woodcreeper (Dendrocolaptes platyrostris) and the melanocortin-1 receptor gene (MC1R). Revista Brasileira de Ornitologia 21: 1-4.

Farnsworth A. \& Lebbin D. 2017. Fuscous Flycatcher (Cnemotriccus fuscatus). In: del Hoyo J., Elliott A., Sargatal J., Christie D.A. \& de Juana E. (eds.). Handbook of the birds of the world alive. Available in http://www.hbw.com/node/57348 (access on 27 September 2017)

Farrell L.L., Küpper C., Burke T. \& Lank D.B. 2014. Major breeding plumage color differences of male Ruffs (Philomachus pugnax) are not associated with coding sequence variation in the MC1R gene. Journal of Heredity 106: 211-215.

Fitzpatrick J.W., Bates J., Bostwick K., Caballero I., Clock B., Farnsworth A., Hosner P., Joseph L., Langham G., Lebbin D., Mobley J., Robbins M, Scholes E., Tello J., Walther B. \& Zimmer K. 2004. Family Tyrannidae (tyrant-flycatchers), p. 170-462. In: del Hoyo J., Elliott A. \& Christie D.A. (eds.). Handbook of the birds of the world, v. 9 (cotingas to pipits and wagtails). Barcelona: Lynx Editions.
Galván I. \& Jorge A. 2015. The rusty plumage coloration of juvenile Gyrfalcons is produced by pheomelanin and its expression is affected by an intracellular antioxidant. Journal of Raptor Research 49: 59-65.

García-Borrón J.C., Sánchez-Laorden B.L., Jiménez-Cervantes C. 2005. Melanocortin-1 receptor structure and functional regulation. Pigment Cell and Melanoma Research 18: 393-410.

Gomez D. \& Théry M. 2004. Influence of ambient light on the evolution of colour signals: comparative analysis of a Neotropical Rainforest bird community. Ecology Letters 7: 279-284.

Gunnarsson U., Kerje S., Bed'hom B., Sahlqvist A.-S., Ekwall O., Tixier-Boichard M., Kämpe O. \& Andersson L. 2011. The dark brown plumage color in chickens is caused by an $8.3-\mathrm{kb}$ deletion upstream of SOX10. Pigment Cell and Melanoma Research 24: 268-274.

Harrigan R.J., Mazza M.E. \& Sorenson M.D. 2008. Computation vs. cloning: evaluation of two methods for haplotype determination. Molecular Ecology Resources 8: 1239-1248.

Hewitt G.M. 1988. Hybrid zones: natural laboratories for evolutionary studies. Trends in Ecology and Evolution 3: 158-167.

Hoekstra H. \& Price T. 2004. Parallel evolution is in the genes. Science 303: $1779-1781$.

Johnson J.A., Ambers A.D. \& Burnham K.K. 2012. Genetics of plumage color in the Gyrfalcon (Falco rusticolus): analysis of the melanocortin-1 receptor gene. Journal of Heredity 103: 315-321

Kang D.Y. \& Kim H.C. 2015. Functional relevance of three proopiomelanocortin (POMC) genes in darkening camouflage, blind-side hypermelanosis, and appetite of Paralichthys olivaceus. Comparative Biochemistry and Physiology B: Biochemistry and Molecular Biology 179: 44-56.

Kerje S., Lind J., Schutz K., Jensen P. \& Andersson L. 2003. Melanocortin 1-receptor (MC1R) mutations are associated with plumage colour in chicken. Animal Genetics 34: 241-248.

Legagneux P., Clark R.G., Guillemain M., Eraud C., Théry M. \& Bretagnolle V. 2012. Large-scale geographic variation in iridescent structural ornaments of a long-distance migratory bird. Journal of Avian Biology 43: 355-361.

Luna L.W., Silva W.A.G., Araripe J., Pereira I.T.F., d'Horta F.M., Sampaio I., Schneider H. \& Rêgo R.S. 2018. Mutations in the melanocortin-1 receptor $(M C 1 R)$ gene have no influence on the distinct patterns of melanic plumage found in the manakins of the genus Antilophia (Aves: Pipridae). Anais da Academia Brasileira de Ciências 90: 2873-2879.

MacDougall-Shackleton E.A., Blanchard L. \& Gibbs H.L. 2003. Unmelanized plumage patterns in Old World Leaf Warblers do not correspond to sequence variation at the melanocortin-1 receptor locus (MC1R). Molecular Biology and Evolution 20: $1675-1681$.

McLean C.A. \& Stuart-Fox D. 2014. Geographic variation in animal colour polymorphisms and its role in speciation. Biological Reviews 89: 860-873.

McNaught M.K. \& Owens I.P.F. 2002. Interspecific variation in plumage colour among birds: species recognition or light environment? Journal of Evolutionary Biology 15: 505-514.

Mercadante A. \& Hill G.E. 2014. An experimental test of the role of structural blue and melanin-based chestnut coloration in aggressive contest in male Eastern Blue Birds. Frontiers in Ecology and Evolution 2: 24.

Miwa M., Inoue-Murayama M., Aoki H., Kunisada T., Hiragaki T., Mizutani M. \& Ito S. 2007. Endothelin receptor B2 (EDNRB2) is associated with the panda plumage colour mutation in Japanese Quail. Animal Genetics 38: 103-108.

Mundy N. 2005. A window on the genetics of evolution: MC1R and plumage colouration in birds. Proceedings of the Royal Society of London B: Biological Sciences 272: 1633-1640.

Oribe E., Fukao A., Yoshihara C., Mendori M., Rosal K.G., Takahashi S. \& Takeuchi S. 2012. Conserved distal promoter of the agouti 
signaling protein (ASIP) gene controls sexual dichromatism in chickens. General and Comparative Endocrinology 177: 231-237.

Osorio D. \& Vorobyev M. 2008. A review of the evolution of animal colour vision and visual communication signals. Vision Research 48: 2042-2051.

Ran J.S., You X.Y., Jin J., Zhou Y.G., Wang Y. Dan L., Ren P. \& Liu Y.P. 2016. The relationship between MC1R mutation and plumage color variation in Pigeons. BioMed Research International 2016: 3059756 .

Rasmussen P.C. \& Collar N.J. 2002. Family Bucconidae (puffbirds), p. 102-138. In: del Hoyo J., Elliott A. \& Christie D.A. (eds.). Handbook of the birds of the world, v. 7 (jacamars to woodpeckers). Barcelona: Lynx Editions.

Robbins L., Nadeau J.H., Johnson K.R., Kelly M.A., Roselli-Rehfuss L., Baack E., Mountjoy K.G. \& Cone R.D. 1993. Pigmentation phenotypes of variant extension locus alleles result from point mutations that alter MSH receptor function. Cell 72: 827-834.

Rozas J., Sánchez-DelBarrio J.C., Messeguer X. \& Rozas R. 2003. DnaSP, DNA polymorphism analyses by the coalescent and other methods. Bioinformatics 19: 2496-2497.

Sanger F., Nicklen S. \& Coulson A.R. 1977. DNA sequencing with chain-termination inhibitors. Proceedings of the National Academy of Sciences of the United States of America 74: 5463-5468.

Seddon N., Botero C.A., Tobias J.A., Dunn P.O., MacGregor H.E.A., Rubenstein D.R., Uy J.A.C., Weir J.T., Whittingham L.A. \& Safran R.J. 2013. Sexual selection accelerates signal evolution during speciation in birds. Proceedings of the Royal Society of London B: Biological Sciences 280: 20131065.

Stoddard M.C. \& Prum R.O. 2011. How colorful are birds? Evolution of the avian plumage color gamut. Behavioral Ecology 22: 1042-1052.

Tajima F. 1989. Statistical method for testing the neutral mutation hypothesis by DNA polymorphism. Genetics 123: 585-595.

Takeuchi S., Suzuki H., Yabuuchi M. \& Takahashi S. 1996. A possible involvement of melanocortin 1-receptor in regulating feather color pigmentation in the chicken. Biochimica et Biophysica Acta (BBA) - Gene Structure and Expression 1308: 164-168.

Theron E., Hawkins K., Bermingham E., Ricklefs R.E. \& Mundy N.I. 2001. The molecular basis of an avian plumage polymorphism in the wild: a melanocortina-1-receptor point mutation is perfectly associated with the melanic plumage morph of the Bananaquit, Coereba flaveola. Current Biology 11: 550-557.

Uy J.A.C., Moyle R.G., Filardi C.E. \& Cheviron Z.A. 2009. Difference in plumage color used in species recognition between incipient species is linked to a single amino acid substitution in the melanocortin-1 receptor. American Naturalist 174: 244-254.

Uy J.A.C., Cooper E.A., Cutie S., Concannon M.R., Poelstra J.W., Moyle R.G. \& Filardi C.E. 2016. Mutations in different pigmentation genes are associated with parallel melanism in island flycatchers. Proceedings of the Royal Society of London B: Biological Sciences 283: 20160731.

Vidal O., Araguas R.M., Fernández R., Heras S., Sanz N. \& Pla C. 2010. Melanism in Guinea Fowl (Numida meleagris) is associated with a deletion of phenylalanine-256 in the MC1R gene. Animal Genetics 41: 656-658.

Wen L., Fu Y., Dai B. \& Antalffy J. 2015. Polymorphism in some birds of Galliformes. Acta Ecologica Sinica 35: 103-106.

Xu Y., Zhang X.H. \& Pang Y.Z. 2013. Association of tyrosinase (TYR) and tyrosinase-related protein 1 (TYRP1) with melanic plumage color in Korean Quails (Coturnix coturnix). Asian-Australasian Journal of Animal Sciences 26: 1518-1522.

Zhang X.H., Pang Y.Z., Zhao S.J., Xu H.W., Li Y.L., Xu Y., Guo Z. \& Wang D.D. 2013. The relationship of plumage colours with MC1R (melanocortin 1 receptor) and ASIP (agouti signaling protein) in Japanese Quail (Coturnix coturnix japonica). British Poultry Science 54: 306-311.

Associate Editor: Fábio R. Amaral. 